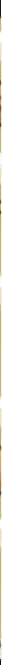

Editor:

Jaime Almansa Sánchez

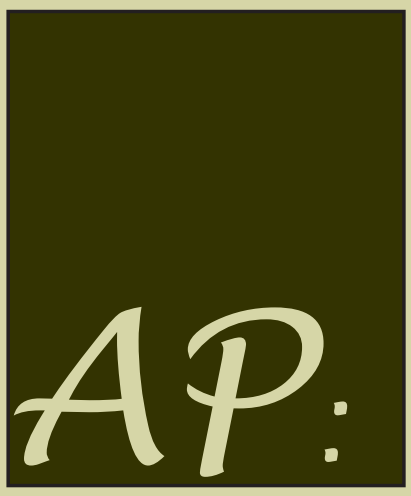

www.arqueologiapublica.es

Ontine Journat in Public Archaeology 


\title{
EDITORIAL
}

\section{Public Archaeology in debate}

\author{
Jaime ALMANSA SÁNCHEZ, Editor \\ JAS Arqueología S.L.U.
}

Piece by piece this journal is growing. That is why, before saying anything else, we need to thank every follower and collaborator for being there for us. Volume 2 comes full of new ideas, projects and perspectives on Public Archaeology.

During the past few months I have struggled with the crisis and Spanish archaeology. Both have been tough to deal with and none has been resolved yet. It is a fact that current management models are in a crisis, and we need -in some countries more than others- to rethink and redefine our role as professionals and adapt to this changing world. It does not matter if we work in the public or the private sector; archaeology has become a commodity whether we like it or not, and its value is not what we usually expect. One of the main roles of Public Archaeology is to design a more efficient and sustainable practice, keeping in mind the social role of our work and our responsibilities towards Heritage.

In this volume, alternative archaeologies, new forms of communication with the public and with other professionals, as well as the threats posed by these issues, fill the following pages.

First of all, the role and dangers of Public Archaeology are discussed in two forums. In this new section of the journal, current debates of interest for the discipline will take place, with the participation of established as well as new researchers worldwide. Therefore, we encourage you to propose topics, no matter where you come from. This volume introduces the first forum, led by Tom King, about the dangers of doing Public Archaeology. In it, we are able to encounter different conceptions of our work, as well as some important issues to take into account when working. The second forum focuses on an event that took place last winter: the lecture of Semir Osmanagic in Linnaeus University. What are the limits of our approach to alternative archaeologies? 
In this volume I present a short paper on our relations with alternative archaeologies, or how to 'fight' them. Also, this volume's Points of You is the story of a 'turned' pseudo that today is a great asset for archaeology.

The next two articles deal with new technologies used for archaeology. The first one is about an innovative experience in Philadelphia; the use of a "10 meter-tall LED light marquee encircling the 27th floor of a city skyscraper", making sure everyone gets the message. In the second, Nicolas Laracuente explores the world of Twitter and the possibilities it offers for communication in archaeology, in and outside professional networks. We have to be aware of all the developments in social media and be imaginative to use these resources for our own good and the good of archaeological heritage. Recently, many initiatives have arisen, adapting new ideas and technologies, such as crowdfunding, probably one of the most interesting in this climate of cuts. As I am writing these lines, two new projects are being implemented: digventures.com and commonsites.net (please visit both). It is still early to see their impacts, but we need to be positive.

But how do we see Public Archaeology? To close that circle, Doug Rock-Macqueen explores with a survey our conception of public outreach and education in archaeology (one of the sides of Public Archaeology).

If last year we lacked reviews, this volume comes with eight. Starting with three interesting (hand)books, we are able to explore various examples of Public Archaeology practices around the world (Okamura and Matsuda's New Perspectives in Global Public Archaeology and Skeates, McDavid and Carman's The Oxford Handbook of Public Archaeology) and a concise review of archaeology by Martin Carver in Making Archaeology Happen. Design versus Dogma. Next, is the future of Spanish Archaeology (El futuro de la arqueología en España), a book edited by myself with the participation of another 44 professionals, followed by the new edition of Praetzellis' "novel" (Death by Theory. A tale of mystery and archaeological theory). Archaeology 2.0 (Kansa, Kansa and Watrall) takes us back to the web and the digital media that are also being discussed in the session thereon celebrated in the last TAG in Birmingham. Finally, Daniel Saucedo reviews the first International Symposium on Public Archaeology which took place last September in Peru.

This year's volume is double in size thanks to your participation. For the coming years, we hope the journal keeps growing in quality and content. At least, for the time being, we can ensure a third volume. 
Looking back into the recent past, we celebrated our first year of existence with a small contest: "What makes \#pubarch important?" Gabriel Moshenska won with his 50-words answer:

"Public archaeology is the study of archaeology in context. This includes social, political, economic and intellectual contexts: a big responsibility for a little sub-discipline. Archaeology is produced and consumed: by studying these processes in all their dimensions public archaeologists are the conscience of the discipline. We are all public archaeologists."

Looking at the present, we hope you will enjoy this new volume, and looking to the future, we hope to see you again next year.

\section{$* * * * *$}

Before closing this editorial, we should make 4 fast announcements (again):

\section{Call for debate:}

Our Facebook page has been changed twice since last year. We do not see it very open for debate right now, and our experience on creating debate in the web has not been very positive besides few examples. But sometimes, debates happen online. Both forums this year started in the WAC mail list and several blogs. That is why I would like to encourage you to participate in debates, wherever the action is, and if you find a topic interesting, bring it to the journal.

\section{Call for papers:}

After Volume 2, Volume 3 will be published in 2013. We still have an open call for papers, which you can submit whenever you prefer. As publication in January seems a utopia, we have set March as the publishing month. Anyway, we need to keep the deadline for submissions in autumn in order to have enough time, especially if the number of papers received keeps increasing. We hope to receive new papers as soon as possible, which will give us time to work patiently. For any suggestions, or if you have any doubts, email us. 


\section{Call for specials:}

We will also be publishing special issues focusing on different topics. Our first call is for the AP Journal Special Issue titled "Public Archaeology in vast infrastructure works", for which we are looking for papers on the archaeology conducted in megaconstructions, such as airports, undergrounds, highways, etc., from the perspective of Public Archaeology in any of its aspects (political and economic issues, education programs practiced, management, etc.). We encourage you to participate in it if you are in some way related to any relevant project. In the past year, it was quite difficult to find papers, so please forward this message and participate. Submissions will remain open until we have enough material. If you have any questions or doubts, once again, please do not hesitate to contact us.

We will also gladly accept new proposals for other special issues. You can suggest a topic and we will decide and agree the terms, always according to the rules of the journal. We have already accepted a proposal for a volume devoted to Didactic that will be promoted soon. So, if you have in mind a volume with a subject related to Public Archaeology, please contact us and we will consider it.

\section{Call for donations:}

As long as JAS Arqueología is alive, it will take care of this journal. As you already know, AP is a free-access and not-for-profit journal. Thus, maintaining it is expensive, both in money and time invested. The philosophy of the journal is to provide the widest access at the lowest cost, but in order to not only improve the quality and efficiency of the content, but also continue its publication, there is a need for funding that depends on you. Donations of any amount will be truly appreciated. This year we would like to once again warmly thank Giannis and Vicky for their generous donation, which is helping a lot to ensure the near future of the journal. We also wish to thank Mayca Rojo, who joined the list of donors this year.

Your contribution will make the future of this journal possible.

Remember there are two ways of contribution:

-Direct donation via Paypal on our web page.

-Purchase of the paper version. There will be a fixed price of $30 €$. Just ask us. 


\section{AP: Ontine Journat in Public Archaeology}

Editor:

Jaime Almansa Sánchez

Email: almansasanchez@gmail.com

Assistant editor:

Elena Papagiannopoulou

Edited by:

JAS Arqueología S.L.U.

Website: www.jasarqueologia.es

Email: jasarqueologia@gmail.com

Address: Plaza de Arteijo 8, T-2, 28029 - Madrid (Spain)

--

Cover Image: Storyboard for a PSA in Philly (H. Winograd and M. Haas)

Copyright (C) 2012 JAS Arqueología S.L.U. (edition) \& Authors (content)

ISSN: $2171-6315$

Quotation:

Almansa, J. 2012. Editorial: Public Archaeology in Debate. AP Journal Vol. $2,1-4$.

AP Journal is a peer-reviewed journal devoted exclusively to Public Archaeology. It is freely distributed online on the Website:

www.arqueologiapublica.es

You can also follow us on:

Blogger:

= http://arqueologiapublica.blogspot.com/

Twitter:

http://twitter.com/APjournal

Facebook:

http://www.facebook.com/APJournal 